Volume 16

Summer 2000

\title{
Acknowledging the Hypocrisy: Granting Minors the Right to Choose Their Medical Treatment
}

Christine M. Hanisco

Follow this and additional works at: https://digitalcommons.nyls.edu/journal_of_human_rights

Part of the Law Commons

\section{Recommended Citation}

Hanisco, Christine M. (2000) "Acknowledging the Hypocrisy: Granting Minors the Right to Choose Their Medical Treatment," NYLS Journal of Human Rights: Vol. 16 : Iss. 3 , Article 5.

Available at: https://digitalcommons.nyls.edu/journal_of_human_rights/vol16/iss3/5

This Notes and Comments is brought to you for free and open access by DigitalCommons@NYLS. It has been accepted for inclusion in NYLS Journal of Human Rights by an authorized editor of DigitalCommons@NYLS. 


\section{NOTES \& COMMENTS}

\section{Acknowledging the Hypocrisy: Granting Minors the Right to Choose Their Medical Treatment}

\section{INTRODUCTION}

Traditionally, minors have been considered dependents of their parents and who do not have any legal rights. ${ }^{1}$ Specifically, they are dependent on their parents until they reach the age of majority. As such, a minor is legally unable to provide or withhold consent to medical procedures. ${ }^{2}$ That legal incapacity to give informed consent has resulted in numerous cases where a minor has been subjected to medical treatment that was against his or her wishes or was unable to obtain treatment that a parent has chosen to withhold. ${ }^{3}$

Legislatures and courts have carved out exceptions to this rule during the past century. For example, a minor may obtain adult legal status, despite his or her age, through the statutory process of emancipation. ${ }^{4}$ Once emancipated, the minor is bestowed with both the rights and responsibilities of adulthood. ${ }^{5}$ The United States Supreme Court created another exception by extending the fundamental right of privacy and bodily integrity to minors with respect to terminating a pregnancy ${ }^{6}$ and obtaining contraception. ${ }^{7}$ In

${ }^{1}$ See Susan D. Hawkins, Note, Protecting the Rights and Interests of Competent Minors In Litigated Medical Treatment Disputes, 64 FORDHAM L. REV. 2075, 2076 (1996) (surveying the history of children's legal rights); see also Jay C. Laubscher, Note, A Minor of 'Sufficient Age and Understanding' Should Have the Right to Petition for the Termination of the Parental Relationship, 40 N.Y.L. SCH. L. REV. 565, 568 (1996) (discussing the common law background and constitutional rights of minors).

${ }^{2}$ See Hawkins, supra note 1, at 2079-80.

${ }^{3}$ See infra notes 148-151 and accompanying text.

${ }^{4}$ See infra Part III.A.

${ }^{5}$ See generally Laubscher, supra note 1, at 577-80.

${ }^{6}$ See Planned Parenthood v. Danforth, 428 U.S. 52 (1976) [hereinafter Danforth].

${ }^{7}$ See Carey v. Population Services International, 431 U.S. 678 (1977). 
the state law context, many states have enacted statutes that allow minors to obtain treatment for sexually transmitted diseases and alcohol and substance abuse, regardless of age, without parental knowledge or consent. ${ }^{8}$ A few states have completely eliminated the parental consent requirement for medical treatment and now allow a "mature minor" to make his or her own medical treatment decisions. 9

Part I of this note discusses the traditional legal status of children and the impact of parental and state interests, rooted in constitutional law, on that status. ${ }^{10}$ Part II examines the common law, legislative, and court created exceptions to the traditional legal disabilities of minors. ${ }^{11}$ The legal requirement for informed consent prior to receiving medical treatment and an adolescent's ability to give informed consent are discussed in Part III. ${ }^{12}$ Part IV discusses the process that physicians should undertake in allowing their adolescent patients to participate in deciding their medical treatment. ${ }^{13}$ Also considered are alternatives to litigation for resolving any conflicts that arise and, if and when courts are involved in the dispute, the proper role of judges. ${ }^{14}$ The facts above support the proposition that the current exception to traditional dependency doctrine is inconsistent with the best interests of the minor. Specifically, the exceptions undermine the minor's interests because they create a paradox that denies mature minors, capable of making responsible decisions, the legal ability to make medical decisions, ${ }^{15}$ but grants immature minors

${ }^{8}$ See Janine P. Felsman, Note, Eliminating Parental Consent and Notification for Adolescent HIV Testing: A Legitimate Statutory Response to the AIDS Epidemic, 5 J.L. \& POL'Y 339, 353-54 (1996).

${ }^{9}$ See Nancy Batterman, Under Age: A Minor's Right to Consent to Health Care, 10 TOuro L. Rev. 637, 641 (1994).

${ }^{10}$ See infra notes $17-56$ and accompanying text.

11 See infra notes 59-147 and accompanying text.

12 See infra notes 148-189 and accompanying text.

${ }^{13}$ See infra notes 192-227 and accompanying text.

14 See infra notes 228-243 and accompanying text.

15 For example, requiring parental consent for withholding medical treatment. See infra notes 167-171. 
the ability to make critical life decisions. ${ }^{16}$

\section{THE Legal Status OF CHILDREN}

Throughout most of United States history, children were regarded as chattel, lacking any legal rights. ${ }^{17}$ The law focused instead on the rights of parents with respect to their children. ${ }^{18}$ Since minor children was completely dependent on their parents, they were under a legal disability. ${ }^{19}$ This legal disability precluded minors from establishing their own domicile, from entering into binding contracts, from consenting to any type of medical, dental, or psychiatric treatment, from bringing a civil action, from making a will, and from conveying real property. ${ }^{20}$ The view that children are more than mere property is a relatively new concept. ${ }^{21}$

The Industrial Revolution marked the beginning of a shift in society's perception of children. ${ }^{22}$ Child labor laws and compulsory education laws were enacted as a way to protect children from the effects of industrialization. ${ }^{23}$ However, despite these progressions, the common law continued to regard minors as mentally incompetent, and

16 For example, allowing a minor to terminate her pregnancy without parental consent. See infra Part III.B.

${ }^{17}$ See Hawkins, supra note 1, at 2076.

${ }^{18} \mathrm{Id}$.

${ }^{19}$ See Laubscher, supra note 1, at 568.

${ }^{20} I d$. at 568-69 (listing these and other traditional legal disabilities of children).

21 See Lynne Marie Kohm \& Maria E. Lawrence, Sex at Six: The Victimization of Innocence and Other Concerns Over Children's "Rights," 36 BRANDEIS J. FAM. L. 361, 369 (1997-98) (describing the historical background on the law and society's perception of childhood).

${ }^{22}$ See Hawkins, supra note 1, at 2076.

23 Id. See also DAVID J. RothMAN, CONSCIENCE AND CONVENIENCE: The ASYlum AND ITS Alternatives IN PROgressive AMERICA 205-12 (1980) (discussing the influence of the progressives on the adoption of child welfare measures including labor and education laws). 
thus applied a legal presumption of incapacity. ${ }^{24}$.

The presumption of incapacity was prevalent in both civil and criminal law. ${ }^{25}$ For instance, a minor could not be held liable for an intentional tort, because it was presumed that he or she was unable to formulate the requisite intent. ${ }^{26}$ Criminal law presumed that young children were unable to formulate the necessary mens rea element of a crime and therefore, could not be held culpable. ${ }^{27}$ These beliefs continued basically unchanged until the Twentieth Century. ${ }^{28}$

During the second half of the Twentieth Century, many courts and legislatures altered or removed some of the traditional legal disabilities placed on minors. ${ }^{29}$ For example, both tax and criminal law, have "recognized that children under the age of eighteen should sometimes be treated as adults." ${ }^{30}$ The United States Supreme Court's declaration that "constitutional rights do not mature and come into being magically only when one attains the state-defined age of majority,"

Despite this expansion of children's legal rights, a minor still needs the express or implied consent of his or her parents or guardians in order to receive medical treatment. ${ }^{32}$ The notion that children do

24 See generally Jennifer Fouts Skeels, In Re E.G.: The Right of Mature Minors In Illinois to Refuse Lifesaving Medical Treatment, 21 LOY. U. CHI. L.J. 1199, 1209 (1990) (explaining the presumption of incapacity with respect to minors).

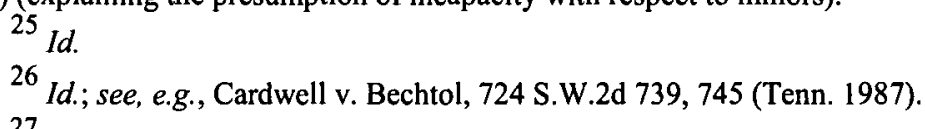

27 See generally Fouts Skeels, supra note 24, at 1209; see also WAYNE R. LaFave \& Austin W. ScotT, Jr., Criminal LaW (2d ed. 1986). The criminal law follows the "Rule of Sevens" for determining capacity of minors to form the required mens rea. Id.

${ }^{28}$ See Hawkins, supra note 1, at 2076.

29 See Laubscher, supra note 1, at 569 (discussing the changes in the law relative to children).

${ }^{30}$ Id.

31 See Planned Parenthood v. Danforth, 428 U.S. 52, 74 (1976) (recognizing that minors possess constitutional rights). See also discussion infra notes 79-90 and accompanying text.

32 See Felsman, supra note 8 , at $347-48$ (describing the common law requirement of parental consent and notification). 
not have the cognitive capacity, experience, and maturity necessary to make complicated life-choices continues to permeate this area of the law. ${ }^{33}$ In addition, there is a belief that parents, in consultation with the child's physician, will make the correct treatment decision; treatment that is in the child's best interest. ${ }^{34}$

\section{A. The Parents' Interest}

The presumption that parents will act in the best interest of their children is rooted in our constitutional law. ${ }^{35}$ In Pierce $v$. Society of Sisters ${ }^{36}$ and Prince v. Massachusetts, ${ }^{37}$ the United States Supreme Court recognized that a fundamental right, embodied in the due process clause of the Fourteenth Amendment, is the parents' "liberty interest in the custody and management of their children, [and] a corresponding duty to provide care."38 Furthermore, in Meyer v. Nebraska the Supreme Court held that parents have an implicit constitutional right to freedom from state intervention in family matters. ${ }^{39}$ The basis for the Meyer Court's decision rested on

${ }^{33}$ Id. at 347-48; see also Bellotti v. Baird, 443 U.S. 622, 634 (1979).

34

See Richard E. Redding, Children's Competence to Provide Informed Consent for Mental Health Treatment, 50 WASH. \& LEE L. REv. 695, 697-98 (1993) (arguing that the assumption that parents always act in the child's best interest is invalid).

${ }^{35}$ See Elizabeth J. Sher, Note, Choosing for Children: Adjudicating Medical Care Disputes Between Parent and the State, 58 N.Y.U. L. REv. 157, 171-72 (1983).

${ }^{36} 268$ U.S. 510 (1925) (holding that a state law mandating parents to send their children to public schools interfered with the parents' liberty to control their children's education).

37321 U.S. 158 (1944) (recognizing that religious freedom and parental autonomy are important, but not without limitation and thus, holding that the state, as parens patriae, could restrict parental control by prohibiting child labor).

${ }^{38}$ See Isabel Traugott \& Ann Alpers, In Their Own Hands: Adolescent's Refusal of Medical Treatment, 151 ARCHIVES OF PEDIATRICS \& ADOLESCENT MEDICINE 922, 923-24 (1997) (discussing the presumption of parental decision making); see also Sher, supra note 35 , at $170-72$ (explaining the basis for parental autonomy in child rearing).

39262 U.S. 390, 399 (1923) (invalidating a Nebraska law, enacted during World War I when anti-German feelings were strong, which banned the teaching of foreign languages in public schools). 
society's acceptance of the premise that parents should be able to make choices for their child, without state intrusion, and that parents typically act in their child's best interests. ${ }^{40}$

This deference to parental authority is driven by two presumptions. First, courts believe that "parents possess what a child lacks in maturity, experience, and capacity for judgment required for making life's difficult decisions." ${ }^{11}$ Second, lawmakers presume that the "natural bonds of affection" cause parents to act in their child's best interests. ${ }^{42}$ Thus, parents, as decision-makers for their children, are given wide latitude in authorizing their medical care and treatment. $^{43}$

\section{B. The State's Parens Patriae Interest}

Despite the widely held belief that parents will act in their child's best interest, parental authority is not absolute. ${ }^{44}$ In fact, if a parent is not acting in the best interest of the child the state may intervene. $^{45}$ The authority for state intervention is based on the doctrine of parens patriae. ${ }^{46}$

${ }^{40}$ See Sher, supra note 35 , at $169,171-72$.

${ }^{41}$ See Parham v. J.R., 442 U.S. 584, 602 (1979). But see Jennifer L. Rosato, The Ultimate Test of Autonomy: Should Minors Have a Right to Make Decisions Regarding Life-Sustaining Treatment?, 49 RUTGERS L. REV. 1, 78-79 (1996) (arguing these presumptions do not apply to life-sustaining treatment).

42 See Parham, 442 U.S. at 602; see also Sher, supra note 35, at 171-72. For example, the Supreme Court has articulated that an "important justification for state deference to parental control over children is that " $[t]$ he child is not the mere creature of the State; those who nurture him and direct his destiny have the right, coupled with the high duty, to recognize and prepare him for additional obligations." Bellotti, 443 U.S. at 637 (quoting Pierce, 268 U.S. at 602).

${ }^{43}$ See Traugott \& Alpers, supra note 38 , at 924.

${ }^{44}$ See, e.g., Prince, 321 U.S. at 166.

45 See generally Sher, supra note 35, at 157 (contrasting the competing interests of parents and the state in medical treatment of minors); see also Traugott \& Alpers, supra note 38, at 924 (arguing that the best interest of the child should always prevail, even if in opposition with the parents and the state's interest).

46 "'Parens patriae' literally 'parent of the country,' refers traditionally to [the] role of [the] state as sovereign and guardian of persons under legal disability, such as juveniles. It is the principle that the state must care for those who cannot take care of 
Although the history of the parens patriae doctrine is a somewhat ambiguous, ${ }^{47}$ it has come to mean that the state has an obligation and a right to protect the interests of its legally disabled citizens, those who can not protect themselves, including children. ${ }^{48}$ The Supreme Court validated the parens patriae concept in Prince $v$. Massachusetts. ${ }^{49}$ In Prince, the Court stated that "neither rights of religion nor rights of parenthood are beyond limitation. Acting to guard the general interest in youth's well being, the state as parens patriae may restrict the parent's control by requiring school attendance, regulating or prohibiting the child's labor, and in many other ways." ${ }^{, 50}$ Some of the state's interests that support parens patriae include preservation of human life, ensuring a productive and self-perpetuating society, and, at the same time, conserving the state's resources. $^{51}$

The state typically evokes its parens patriae authority with respect to children when parents have jeopardized or threatened their child's health and safety. ${ }^{52}$ Based on the belief that a child has the "might to live and to grow up with a sound mind in a sound body,"53 the state will exercise its authority and intervene in the parent-child relationship. $^{54}$ In the medical arena, the state is mostly likely to

themselves, such as minors who lack proper care and custody from their parents." BLACK'S LAW DiCTIONARY 1114 (6th ed. 1990).

${ }^{47}$ See In re Gault, 387 U.S. 1, 16 (1967) (stating that the meaning of parens patriae is "murky and its historic credentials are of dubious reliance.").

${ }^{48}$ See Sher, supra note 35, at 170; see also Hawkins, supra note 1, at 2084.

49321 U.S. at 165 (holding that a state's authority over the conduct of children exceeds its authority to control the conduct of adults).

50 Id. at 166. See also Schleifer v. Charlottesville, 159 F.3d 843 (4th Cir. 1998) (holding municipal curfew law over parental objections constitutional).

${ }^{51}$ See Hawkins, supra note 1, at 2085; see also Rosato, supra note 41, at 70.

52 See generally Walter Wadlington, David C. Baum Memorial Lecture: Medical Decision Making For and By Children: Tensions Between Parent, State, and Child, 1994 U. ILL. L. REV. 311, 322-23 (1994) (explaining relevance of child abuse reporting statutes to medical treatment cases); see also Hawkins, supra note 1, at 2084.

${ }^{53}$ In re Clark, 185 N.E.2d 128, 132 (Ohio 1962).

54 See Laura M. Plastine, Comment, "In God We Trust": When Parents Refuse Medical Treatment for Their Children Based Upon Their Sincere Religious 
intervene when the child is suffering from a serious and potentially life-threatening illness or injury, not when the child has a minor childhood illness. ${ }^{55}$ Thus, the parent's right to raise their children is not absolute and must give way when the child's life is at risk. ${ }^{56}$

\section{RightS CURRENTLy AFForded AdOLESCENTS DesPite TheIR TRADITIONAL LEGAL DisABILITIES}

It is clear that both parents and the state have legitimate interests in the welfare of children. However, it is unclear where the child fits in. In today's society it is not uncommon for an adolescent to exclaim to their parent or teacher "Don't tell me what to do. I know my rights." In reality, the expansion of minors' legal rights has been minimal, and in fact, these rights are still limited. ${ }^{57}$

\section{A. Emancipation}

Emancipation is the "legal process by which a child is released from the control and authority of his [or her] parent." ${ }^{, 58}$ Most children are automatically emancipated from their parents upon reaching the age of majority, which in most jurisdictions is eighteen. ${ }^{59}$ However,

Beliefs, 3 Seton Hall Const. L.J. 123, 139 (1993) (exploring the right of the state to override parental religious-based objections to their children's medical treatment).

${ }^{55}$ Id. at 139-41 (exploring the parental right to engage in faith-healing even when a child's life is endangered).

${ }^{56}$ Id.

57 See Laubscher, supra note 1, at 569.

58 See 1 Homer H. ClaRK, JR., THE LAW of Domestic Relations IN THE United States 548 (2d ed. 1987). See also Carol Sanger \& Eleanor Willemsen, Minor Changes: Emancipating Children in Modern Times, 25 U. Mich. J.L. REFORM 239, 240 (1992) (discussing use of statutory emancipation by parents as a way of coping and dealing with troubled adolescents).

${ }^{59}$ See Robert F. Weir \& Charles Peters, Affirming the Decisions Adolescents Make About Life and Death, The HASTINGS CENTER ReP., Nov. 11, 1997, at 29, 33. See also Dana F. Castle, Early Emancipation Statutes: Should They Protect Parents as Well as Children?, 20 FAM. L.Q. 343, 348-49 nn.35-36 (1986). After the Twenty-sixth Amendment was enacted, granting the right to vote to eighteen-year-olds, many jurisdictions lowered the age of majority from twenty-one to eighteen. Today, forty-four 
there are several processes by which an adolescent who has not yet reached his or her eighteenth birthday may be emancipated from his or her parents or guardian and thus, have the rights (and responsibilities) of adulthood conferred upon him or her. ${ }^{60}$ First, in many states, minors are automatically emancipated if they enter military service and marry. ${ }^{61}$

Second, many states have statutes that allow minors who meet the requirements set forth therein to be emancipated from their parents. ${ }^{62}$ For instance, in California, if a minor can demonstrate that he or she: "(1) is at least fourteen years of age; (2) able to manage his or her own affairs; (3) lives separate and apart from parents with either parental consent or acquiescence; and (4) receives income derived from legal activity,"63 the minor may be legally emancipated. ${ }^{64}$ The court is ultimately left with the discretion to deny an emancipation request if it believes doing so would be in the minor's best interest. ${ }^{65}$ One factor this and other statutes do not require a judge to consider is whether the minor is actually competent to live on his or her own. ${ }^{66}$ Instead, the focus is on the minor's independence from his or her parents. ${ }^{67}$

jurisdictions have a statutory age of majority of eighteen. Id. See, e.g., CAL. FAM. CODE $\S 7002$ (West 1994); MICH. CoMP. Laws ANN. $\$ 722.4$ (West 1993 \& Supp. 1995); Mo. REV. STAT. § 452.340.3 (1993); N.J. STAT. ANN. § 9:17B-3 (West 1976); N.C. GEN. STAT. § 50-13.4(c) (1994); W. VA. CODE § 2-3-1 (1992).

${ }^{60}$ See generally Laubscher, supra note 1, at 578-80; John C. Polifka, The Status of Emancipated Minors in lowa: The Case For a Clearly Drafted Statute, 44 DRAKE L. REV. 39, 45-48 (1995) (arguing emancipation statutes are preferable to common law); Batterman, supra note 9 , at 641 .

61 See, e.g., CAL. FAM. CODE $§ 7002$; see also Redding, supra note 34, at 712; Laubscher, supra note 1, at 578.

62 See, e.g., Alaska STAT. $\$ 09.55 .590$ (Miche Supp. 1994); CAL. FaM. CODE $\S \S 7000-143$ (West Supp. 1994); KAN. STAT. ANN. $\S \S 38-108$ to -110 (1993); Mich. COMP. LAWS. ANN. \$§ 722.4-.4e (West 1993).

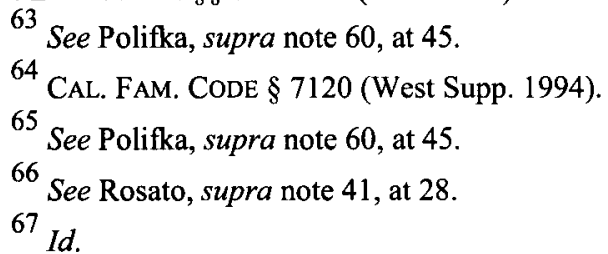


Finally, some states recognize a common law right to emancipation. ${ }^{68}$ In these states, minors petition the court, and " $[\mathrm{t}]$ heir status is judicially determined on a case-by-case basis." 69 The factors enumerated in emancipation statutes tend to be the same ones considered by judges in common law states. ${ }^{70}$ For example, in New York, a common law emancipated minor is one whose parents have surrendered control over the child's behavior and personal affairs. ${ }^{71}$ As a result, the doctrine is typically discussed in cases regarding the payment of child support. ${ }^{72}$

For the minor whose petition for an emancipation decree is granted he or she is bestowed with all of the rights and responsibilities of an adult. ${ }^{73}$ Besides being free from the control and authority of their parents, emancipated minors are able to enter into binding contracts, sue in their own names, establish their own residences, retain their own earnings, receive public assistance, consent to their own medical treatments, execute either living wills or proxy directives. $^{74}$

\section{B. Abortion and Personal Health Rights}

The United States Supreme Court has recognized that the

${ }^{68}$ Id. at 43 (stating that Iowa is a common law emancipation state); see also Batterman, supra note 9, at 645-46.

69 See Polifka, supra note 60, at 43.; see also Smith v. Seibly, 431 P.2d 719 (Wash. 1967) (recognizing that emancipation of minors may occur even in the absence of a statute).

${ }^{70}$ See generally Batterman, supra note 9 , at 641 . Courts will look at whether the minor is living separate and apart from his or her parents; self-supporting; managing his or her own financial affairs; and if emancipating the minor is in his or her best interest. Id.

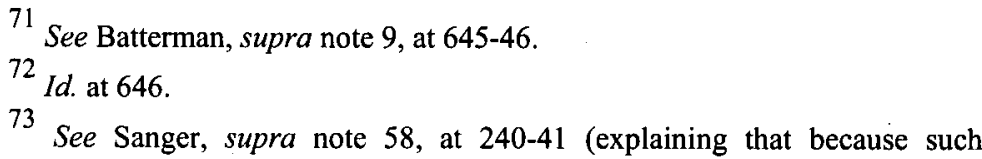
minor's attain legal adulthood prior to reaching the age of majority, such emancipated minors may engage in adult acts, such as signing binding contracts, keeping their own property, and disobeying their parents).

${ }^{74}$ See generally Polifka, supra note 60 , at 47 ; Redding, supra note 34 , at 712; Batterman, supra note 9, at 647-48; Rosato, supra note 41, at 34-35. 
Constitution grants minors a right to privacy. ${ }^{75}$ The reach of these decisions, however, have been primarily limited to the areas of reproductive rights and limited personal health care issues. ${ }^{76}$ The first major step was taken by the Supreme Court in Planned Parenthood $v$. Danforth, ${ }^{77}$ which extended the fundamental privacy right to choose abortion to unmarried, minor women. ${ }^{78}$

In Danforth, the Supreme Court was considering the constitutionality of a Missouri statute that required written parental consent before an unmarried woman under the age of eighteen could have an abortion. ${ }^{79}$ Since the right to choose an abortion flows from a fundamental right to privacy the applicable standard for evaluating the effect of the Missouri statute was strict scrutiny ${ }^{80}$ In its analysis the Court first recognized that minors do have constitutional rights ${ }^{81}$ and declared that the statute imposed an unconstitutional burden on the minor's privacy right. ${ }^{82}$ According to the Court, this burden was a result of the Missouri legislature granting a third party "an absolute,

75 See Jan C. Costello, Making Kids Take Their Medicine: The Privacy and Due Process Rights of De Facto Competent Minors, 31 LoY. L.A. L. REv. 907, 908 (1998) (forwarding that the right to privacy includes, but is not limited to the right to protect bodily integrity and to make health care decisions).

${ }^{76}$ See Fouts Skeels, supra note 24, at 1213.

77

428 U.S. 52 (1976).

${ }^{78}$ See generally Katherine M. Waters, Judicial Consent to Abort: Assessing a Minor's Maturity, 54 GEO. WASH. L. REv. 90, 94-95 (1985); Rosato, supra note 41, at 16 (commenting on the Supreme Court's deferential position on minor's abortion rights).

\footnotetext{
79 Danforth, 428 U.S. at 74.
}

${ }^{80}$ See Roe v. Wade, 410 U.S. 113, 153 \& 155 (1973). Roe established that the right of privacy is broad enough to encompass abortion and reiterated that the right of privacy is a fundamental right triggering strict scrutiny analysis. Id. at 153. A regulation that limits fundamental rights will only survive strict scrutiny if there is a compelling state interest and the regulation is "narrowly drawn to express only the legitimate state interests at stake." Id. at 155.

81 See Danforth, 428 U.S. at 74 . The Danforth Court recognized that "constitutional rights do not mature and come into being magically only when one attains the state-defined age of majority. Minors, as well as adults, are protected by the Constitution and possess constitutional rights." Id.; see also Fouts Skeels, supra note 24, at 1210 .

${ }^{82}$ See Danforth, 428 U.S. at 74. 
and possibly arbitrary, veto over the decision of the physician and his patient to terminate the patient's pregnancy, regardless of the reason for withholding the consent." the parents' interest may nevertheless outweigh the minor's right of privacy. ${ }^{84}$ However, the Court concluded "[a]ny independent interest the parent may have in the termination of the minor daughter's pregnancy is no more weighty than the right of privacy of the competent minor mature enough to have become pregnant. ${ }^{, 85}$

Nevertheless, the Supreme Court placed a limitation on the minor's fundamental right to choose an abortion. ${ }^{86}$ The Court stated: "[O]ur holding ... does not suggest that every minor, regardless of age or maturity, may give effective consent for termination of her pregnancy." minors could choose an abortion without parental consent. ${ }^{88}$ How a minor's maturity was determined was left unanswered ${ }^{89}$ Justice White's dissent criticized the majority's lack of detail in their opinion and stated that states are entitled to protect minors "from their own immature and improvident decisions; and there is absolutely no reason expressed by the majority why the State may not utilize that method here." $" 90$

The next major decision about a minor's fundamental right to choose an abortion was enunciated in Bellotti v. Baird (Bellotti II). ${ }^{91}$ The Bellotti Court held that states must provide an alternative to parental consent for a minor's seeking an abortion. ${ }^{92}$ Accordingly,

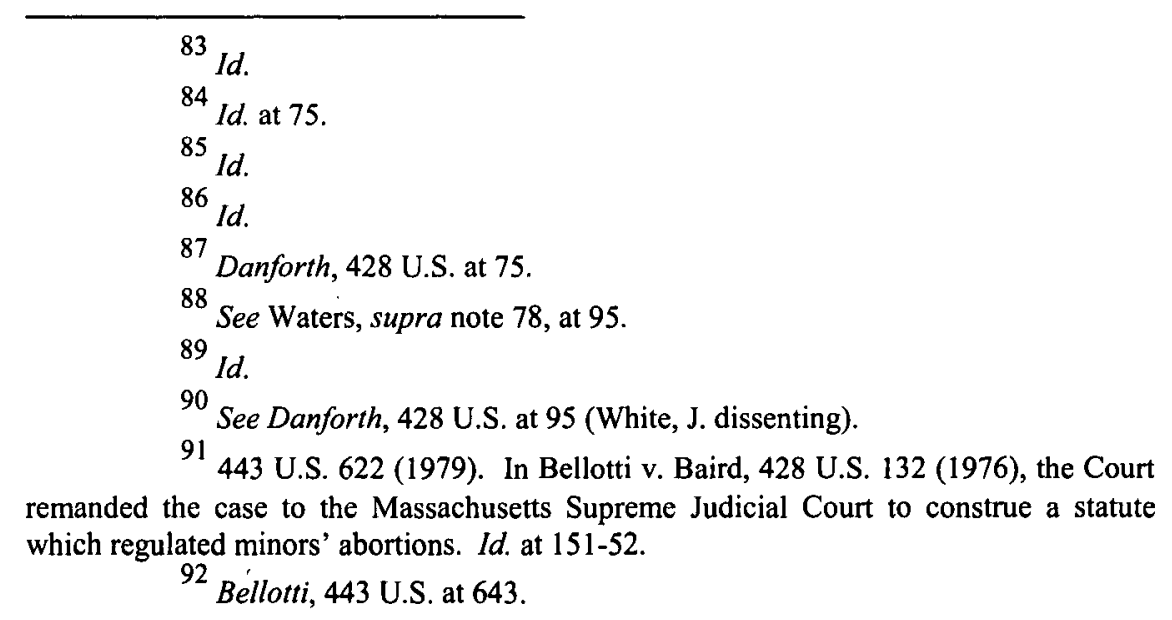


states must afford a minor an alternative procedure in which she can demonstrate that she is "mature enough and well enough informed to make her abortion decision." ${ }^{, 93}$ It is important to note that the burden was on the minor to rebut the presumption that she is incompetent of making decisions about her medical care. ${ }^{94}$ If the court does not believe that the minor is mature enough, the judge may still grant the minor the right to have an abortion without parental consent or notification, as long as it would be in the minor's best interest. ${ }^{95}$

Another pivotal case involving minors and their privacy was Carey v. Population Services International. ${ }^{96}$ In Carey, the Supreme Court addressed a minor's access to contraception. ${ }^{97}$ At issue in Carey was a New York statute which prohibited the distribution of non-medical contraceptives to persons sixteen or older, and entirely prohibited distribution to children under sixteen. ${ }^{98}$ Reiterating the principle that the right to privacy extends to minors as well as adults, the Court found the statute unconstitutional because the state failed to show a significant interest that outweighs the minors right to privacy. ${ }^{99}$

In addition to reproductive rights, minors have been granted minimum rights in other areas of personal health. ${ }^{100}$ These laws are

93 Id.

${ }^{94}$ See Costello, supra note 75, at 909-10; see also Satsie Veith, The Judicial Bypass Procedure and Adolescents' Abortion Rights: The Fallacy of the "Maturity" Standard, 23 HofsTRA L. REv. 453, 455 (1994).

95 See Bellotti, 443 U.S. at 650.

96431 U.S. 678 (1977).

97 Id.

98 Individuals sixteen years of age and older were able to receive contraceptives from a licensed pharmacist. Id. at 681-82; see also Hawkins, supra note 1, at 2097-98.

99 See Carey, 431 U.S. at 694-96; see also Hawkins, supra note 1, at 2098; Jessica A. Penkower, The Potential Right of Chronically Ill Adolescents to Refuse LifeSaving Medical Treatment - Fatal Misuse of the Mature Minor Doctrine, 45 DEPAUL L. REV. 1165, 1182-83 (1996).

${ }^{100}$ See Penkower, supra note 99, at 1178 (including sexually transmitted diseases, alcohol and substance abuse, and psychiatric care). 
often referred to as age of consent laws ${ }^{101}$ and usually involve medical decisions relating to treatment of sexually transmitted diseases, alcohol, and substance abuse. ${ }^{102}$ These statutory exceptions to the common law rule requiring parental consent for medical treatment of minors evolved due to the increase of sexually transmitted diseases among adolescents and the perception that adolescents would not seek treatment if they needed to first inform their parents. ${ }^{103}$ Neither the minor's maturity or decision-making capacity were factors in the passing of these laws. ${ }^{104}$ Further, the laws focus upon a minor's right to consent to treatment, not his or her right to refuse treatment. ${ }^{105}$ Statutes that permit minors to obtain alcohol and substance abuse treatment, and mental health care were enacted on the same premise. $^{106}$

\section{The Mature Minor Doctrine}

The "mature minor" doctrine is a relatively new legal concept which allows some minors to consent to medical treatment without parental consent. ${ }^{107}$ However, only a few states have recognized this doctrine, and the Supreme Court has yet to declare it applicable to

${ }^{101}$ See generally Redding, supra note 34 , at 712 ; Rosato, supra note 41 , at

102 See, e.g., UTAH CODE ANN., § 26-6-18 (1999) (permitting minors to consent to treatment for sexually transmitted diseases without parental consent); N. Y. PUB. HEALTH LAW $\S 2305(2)$ (McKinney 1993) (authorizing diagnosis, treatment and prescription of persons under 21 years of age infected with, or exposed to, sexually transmissible diseases without parental consent); N. Y. MENTAL HYG. LAW $§ 21.11$ (McKinney Supp. 1994) (allowing treatment of minors for substance abuse problems without parental consent if "such treatment is necessary for the best interests of the child"); N.J. STAT. ANN. § 9:17A-4 (West 1993); VA. CODE ANN. § 54-325-2.D (1992); see also Felsman, supra note 8 , at 354 .

${ }^{103}$ See Penkower, supra note 99, at 1178; see also Felsman, supra note 8, at $342-45$.

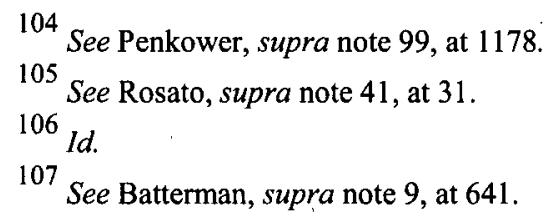


medical treatment decisions outside of reproductive rights. ${ }^{108}$

In an early case, In re Green, ${ }^{109}$ physicians sought to perform a spinal fusion to sixteen year old Ricky Green, who suffered from severe curvature of the spine with accompanying paralytic scoliosis. ${ }^{110}$ However, there was no evidence that the condition was life threatening or that it was necessary to immediately perform the operation. "11 Ricky's mother, however, refused to consent to the procedure since blood transfusions would be necessary. ${ }^{112}$ Although Ricky was initially excluded from the decision-making process, the Supreme Court of Pennsylvania stated that it would be "most anomalous to ignore Ricky in this situation when we consider the preference of an intelligent child of sufficient maturity" $" 113$ and remanded the matter, holding that Ricky's personal choices should be considered. $^{114}$

Several years later, the Tennessee Supreme Court recognized in Cardwell v. Bechtol the mature minor exception to parental consent for medical treatment. ${ }^{115}$. Cardwell involved an action against an

108 Id.; see also Hawkins, supra note 1, at 2100-01. See, e.g., ARK. STAT. ANN. § 20-9-602(7) (Michie 1991) (granting "[a]ny unemancipated minor of sufficient intelligence to understand and appreciate the consequences of the proposed surgical or medical treatment or procedures" the legal ability to consent to said treatment); NEV. REV. STAT. $\S 129.030(2)$ (1991) (stating if a minor "understands the nature and purpose of the proposed examination or treatment and its probable outcome, and voluntarily requests it" his or her consent alone is sufficient). State appellate courts in Georgia, Illinois, Maine, Michigan, Missouri, and Tennessee have held that life-sustaining medical treatment may be withheld or withdrawn from adolescents. See Weir, supra note 59, at 29 (arguing that adolescents are capable of making health care decisions and that advance directives should be used by adolescents to allow them to participate in their treatment).

109 In re Green, 292 A.2d 387 (Pa. 1972), aff'd, 307 A.2d 279 (Pa. 1973).
${ }_{110}$ Id. at 388.
${ }^{111}$ Id.
${ }_{112}$ Id.
113 See In re Green, 292 A.2d at 392.
${ }^{114}$ Id. But see Commonwealth v. Nixon, 718 A.2d 311 (Pa. Super. 1998) (holding mature minor doctrine does not allow a mature minor to refuse medical treatment in life-threatening situations).

115724 S.W.2d 739 (Tenn. 1987); see also Joan-Margaret Kun, Rejecting the Adage "Children Should Be Seen and Not Heard" - The Mature Minor Doctrine, 16 
osteopath who had treated Sandra Cardwell, without the consent of her parents, five months prior to her eighteenth birthday. ${ }^{116}$. The Court noted that several Tennessee laws "recognize[d] the varying degrees of responsibility and maturity of minors [fourteen] years and older,"117 and also considered the "Rule of Sevens" $" 118$ which presumes different levels of capacity depending on the age of the minor. ${ }^{119}$ The court concluded that a mature minor exception to parental consent does exist, however, it affirmed the jury's verdict that Sandra did not have capacity to consent and did not effectively consent to treatment. ${ }^{120}$

Two years later, the Illinois Supreme Court in In re E.G., recognized that minors have a common law right to refuse medical treatment. ${ }^{121}$ E.G. was a seventeen and a half-year-old girl with acute nonlymphatic leukemia who needed blood transfusions to treat the disease. ${ }^{122}$ Both E.G. and her mother were Jehovah's Witnesses and refused to consent to the treatment because of their belief that receiving a blood transfusion violates the Bible's prohibition against consuming blood. ${ }^{123}$ The Illinois State Attorney General sought a judicial determination that E.G. was medically neglected and in need of treatment. The trial court agreed and appointed a temporary

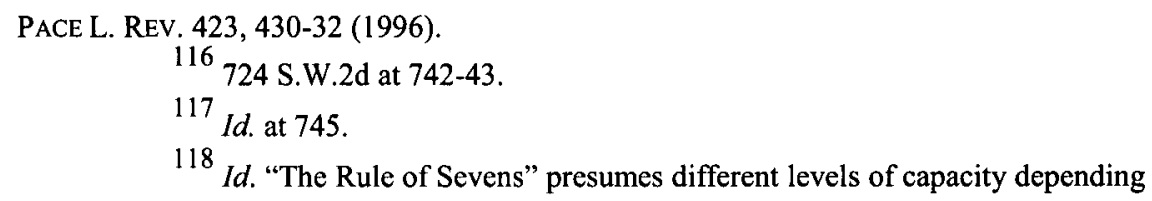
on the age of the child. Id. According to the Rule a child under the age of seven lacks capacity. Id. Between the ages of seven and fourteen there is a rebuttable presumption of lack of capacity. Id. For children between the ages of fourteen and twenty-one there is a rebuttable presumption of capacity. Id. See also Kun, supra note 115, at 431.

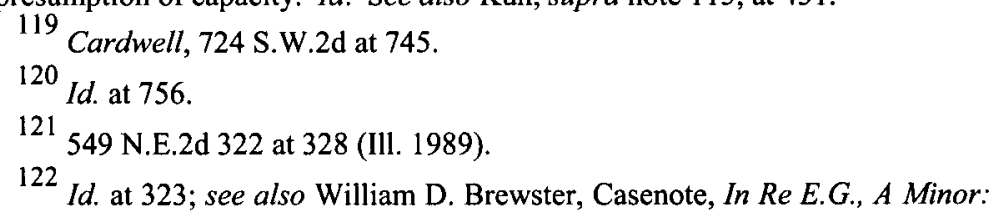
Death Over Life: A Judicial Trend Continues as the Illinois Supreme Court Grants Minors the Right to Refuse Life-Saving Medical Treatment, 23 J. MarShaLl L. ReV. 771, $772-73(1990)$.

${ }^{123}$ See In re E.G., 549 N.E.2d at 323; see also Brewster, supra note 122, at n.14 (citing J. PENTon, APOCALyPSE Delayed: The StORY OF Jehovah's WITNESSES 153 (1985)) "[Jehovah's] Witnesses believe that taking blood transfusions is contrary to the teachings of Genesis 9:4, Leviticus 3:17, and Acts 15:29". Id. 


\section{0] ACKNOWLEDGING THE HYPOCRISY 915}

guardian to make E.G.'s treatment decisions. ${ }^{124}$ On appeal the appellate court held that E.G. was a mature minor and her constitutional right to exercise her religion permitted her to refuse blood transfusions. ${ }^{125}$

The State appealed to the Illinois Supreme Court, which in turn granted certiorari. ${ }^{126}$ Since the United States Supreme Court had not recognized that either adults or minors have a constitutional right to refuse life-saving medical treatment, the court based its decision on case law and Illinois statutes to conclude that a minor, with judicial approval, could refuse medical treatment. ${ }^{127}$ The court stated that in the absence of a statute, a trial judge should determine "whether a minor is mature enough to make health care choices on her own.", 128 However, the court stated that the right must be balanced against four state interests: "(1) the preservation of life; (2) protecting the interests of third parties; (3) prevention of suicide; and (4) maintaining the ethical integrity of the medical profession." longer a minor, the court did not remand the case to the trial court. ${ }^{130}$

The Maine Supreme Judicial Court has also recognized that a minor has a right to refuse life-sustaining procedures. ${ }^{131}$ In In re Swan, Chad Swan was involved in a car accident nine months before his eighteenth birthday that left him in a persistent vegetative state. ${ }^{132}$ The court found clear and convincing evidence that on more than one occasion prior to the accident, Chad had expressed his desire not to be kept on life-sustaining equipment, and therefore, his prior statements were controlling. ${ }^{133}$ Thus, Chad's parents were allowed to determine

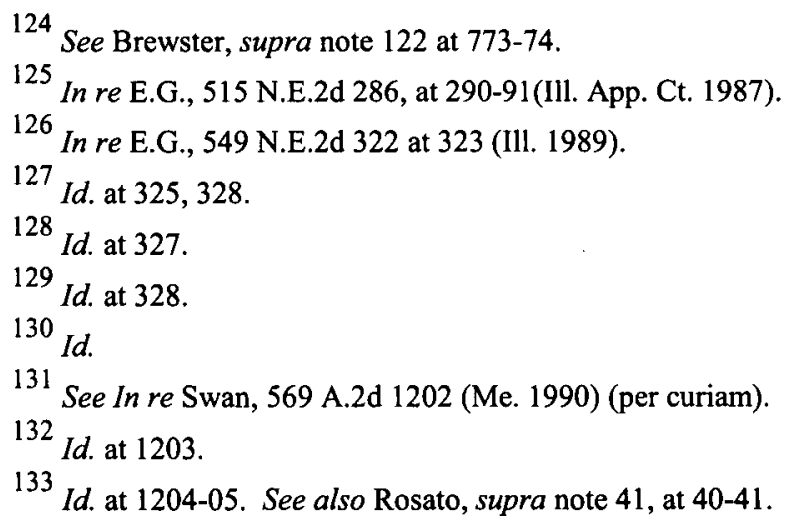


whether or not to re-insert a gastronomy tube. ${ }^{134}$ The court's decision also noted the common law presumption of competency for persons fourteen years and older, ${ }^{135}$ that persons attain capacity at different ages, ${ }^{136}$ and the Illinois Supreme Court's decision in In re E.G.. ${ }^{137}$

Most recently the Massachusetts Appeals Court considered whether a superior court judge erred in entering an order authorizing blood transfusions to a seventeen-year old Jehovah's Witness. ${ }^{138}$ In a pro-adolescents' rights decision, the court vacated the lower court's order. ${ }^{139}$ Because Rena was no longer hospitalized the court concluded the issue was moot and did not remand the case for additional proceedings. ${ }^{140}$ Clearly defining the applicable test, ${ }^{141}$ the court placed particular emphasis on evaluating the minor's maturity. ${ }^{142}$ In addition, the court directed judges to also consider the minor's wishes, if applicable, his or her religious convictions, and to receive testimony directly from the minor. ${ }^{143}$ Accordingly, the Rena decision grants minors the right to determine their medical treatment and if their decision is contested by their parents or physician, they have judicial recourse.

Thus, the mature minor doctrine seeks to balance the privacy interests of the minor with the legitimate interests of the state and the parents. ${ }^{144}$ However, critics have argued that the doctrine is vague

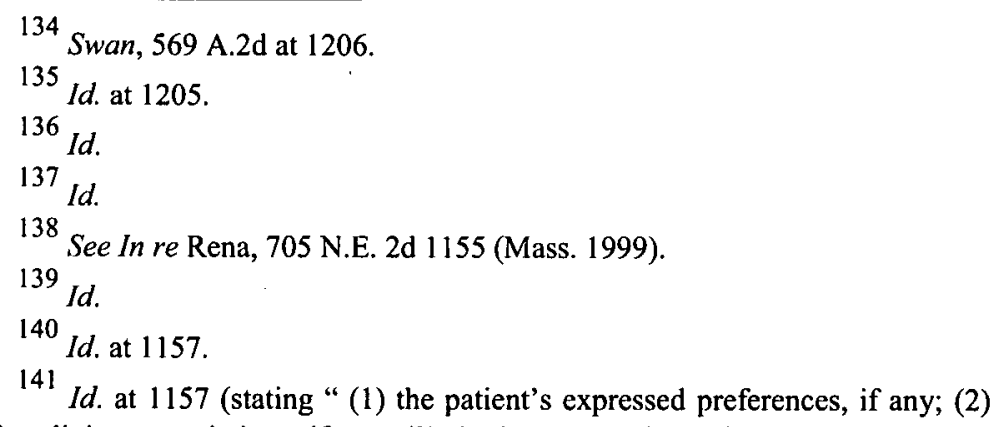
the patient's religious convictions, if any; (3) the impact on the patient's family; (4) the probability of adverse side effects from the treatment; (5) the prognosis without treatment; and (6) the present and future incompetency of the patient in making that decision").

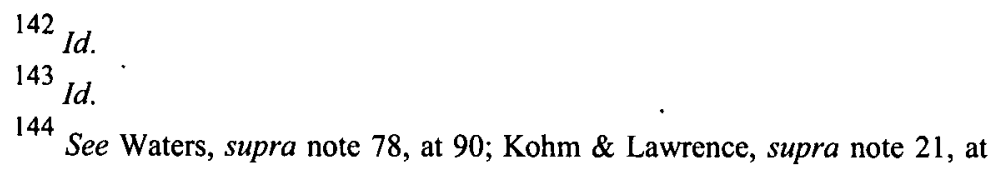


and ambiguous and fails to provide judges with clear guidelines for determining maturity. ${ }^{145}$ Furthermore, other states have refused to adopt the mature minor doctrine. ${ }^{146}$ As a result, minors in only a few states may rely on the mature minor doctrine to exercise their privacy right to decide their own medical treatment. ${ }^{147}$

\section{The NeEd For Consistency: ExTending PRIVACY Rights AND the Right OF SELF-DETERMINATION TO ADOLESCENTS' MEDICAL TREATMENT}

In Massachusetts, a sixteen-year-old boy ran away from home to avoid chemotherapy treatment despite his parents' consent. ${ }^{148}$ In California, a fifteen year old girl fled her home after being physically forced to succumb to chemotherapy, despite both her parents' and her

376.

145 See Waters, supra note 78, at 92, 98; see also Brewster, supra note 122 , at 779 (arguing that the court's holding. in In re E.G. was incorrect, because it did not adequately consider precedent case law, ignored the fact that blood transfusions were in E.G.'s best interest, and did not recognize the differences between abortion cases and blood transfusions); Rosato, supra note 41 , at 22 (criticizing the courts that apply the mature minor doctrine for being too broad based in analysis).

146 See, e.g., Novak v. Cobb County-Kennestone Hospital Authority, 849 F.Supp. 1559 (N.D. Ga., 1994); In re Long Island Jewish Medical Center, 557 N.Y.S.2d 239 (N.Y. Sup. Ct. 1990) (holding minor could not refuse blood transfusions due to lack of maturity, despite minor being only one month shy of his eighteenth birthday and refusing to adopt a mature minor doctrine); Commonwealth v. Nixon, 718 A.2d 311 (Pa. 1998) (holding parents' have a duty to override their child's refusal of medical treatment in life-threatening situations, despite child's mature minor status); O.G. v. Baum, 790 S.W.2d 839 (Tex. Ct. App. 1990) (distinguishing In re E.G. on the basis that the minor did not testify and that Texas did not have a mature minor standard); see generally Kun, supra note 115 , at $439-41$.

147 See discussion supra Part II.C.

148 See Traugott \& Alpers, supra note 38, at 922-23; Hawkins, supra note 1, at 2075. In 1994, Billy Best of Norwell, Massachusetts ran away to Texas to avoid chemotherapy because "[he] could not stand going to the hospital every week" and felt like the medicine was killing him instead of curing him. See Traugott \& Alpers, supra note 38 , at 923 . After being persuaded to return home through the media, Billy and his parents chose alternative therapy. $I d$. at 923 . 
lack of consent. ${ }^{149}$ Another fifteen-year old who, with parental consent, chose to discontinue his medication and decline a third liver transplant, was forcibly removed by police from his home and hospitalized. ${ }^{150}$ Another fifteen year old, suffering from end-stage cystic fibrosis, was placed on a ventilator despite his repeated wishes against life-prolonging measures, such as intubation and mechanical ventilation.

The laws throughout this country are inconsistent with respect to a minor's ability to make his or her own medical decisions. ${ }^{152}$ Depending on the state, a minor may be able to obtain an abortion or treatment for sexually transmitted diseases, but that same minor may not be able to choose the course of treatment for cancer. ${ }^{153}$ Further, a minor as young as fourteen years old may be declared emancipated, based on financial independence, and may subsequently make his or her own medical decisions. ${ }^{154}$ However, a terminally ill minor who has his or her family's support cannot refuse medical treatment. ${ }^{155}$

${ }^{149}$ See Traugott \& Alpers, supra note 38 , at 923; Hawkins, supra note 1, at 2075. Lee Lor, a Hmong refugee, and her parents believed that "surgically removing the cancer would cause it to recur in someone else" and that Lee would be unable to fill her traditional role in Hmong society if the treatment resulted in infertility. See Traugott, supra note 38, at 923. A court order resulted in the forcible removal of Lee from her home and submission to chemotherapy, which Lee described as "torture." Id. at 923.

${ }^{150}$ See Traugott \& Alpers, supra note 38, at 923. Benny Agrelo was eight years old when he underwent his first liver-transplant. Five years later the a second liver transplant was performed. Id. Following this procedure Benny, which his mother's approval, decided to discontinue his medication therapy based on the desire to have "a few months of health" instead of "long-term survival with pain." Id. At fifteen Benny's doctors wanted to perform a third transplant and Benny and his mother refused, resulting in a court order to hospitalize Benny. Id. Eventually a judge ruled that Benny could return home without resuming his medication. Benny died two months later. Id.

151 See Weir, supra note 59, at 30. C.G. was hospitalized four times during his last year of life and repeatedly stated that he knew he did not have much longer to live and did not want to be on a ventilator. Id.
${ }^{152}$ See Sher, supra note 35, at 159.
153 See, e.g., Kun, supra note 115, at 424-25 (discussing the case of Billy Best who ran away from home after two and one-half months of chemotherapy and learning from doctors that four more months of treatment was required).

\footnotetext{
${ }^{154}$ See supra note 62 and accompanying text.

155

See supra notes 149-150 and accompanying text.
} 


\section{A. Informed Consent}

A patient must give informed consent before a physician may proceed with treatment. ${ }^{156}$ This common law doctrine requires a physician to explain to the patient the diagnosis, treatment options, the risks and benefits of each option, and prognosis. ${ }^{157}$ If a physician fails to explain these issues and fails to obtain the consent of the patient, he or she may be liable for an intentional tort of battery. ${ }^{158}$ This doctrine resulted from common law out of respect for individual autonomy ${ }^{159}$ and continues to allow "individuals the freedom to make certain choices about their lives that comport with their own values."160

The right to be informed about medical treatment and to consent to or refuse treatment is a fundamental right, afforded only to adults. ${ }^{161}$ As early as 1891, the United States Supreme Court declared in.Union Pacific Railway Company v. Botsford" ${ }^{62}$ that "[n]o right is held more sacred, or is more carefully guarded, by the common law, than the right of every individual to the possession and control of his

156 See Penkower, supra note 99, at 1170 (discussing the doctrine of informed consent as it applies to adults); see also Hawkins, supra note 1, at 2093-94; Rosato, supra note 41 , at 10-14.

${ }^{157}$ See Penkower, supra note 99, at 1170; see also Hawkins, supra note 1, at 2093.

${ }^{158}$ See Hawkins, supra note 1, at 2094 (explaining the common law doctrine of informed consent and one's right to make treatment decisions).

${ }^{159}$ See Hawkins, supra note 1, at 2094; see also Penkower, supra note 99, at 1169-70; Redding, supra note 34, at 704-05; Rosato, supra note 41, at 10-11.

${ }^{160}$ See Penkower, supra note 99, at 1169.

161 See Andrew Popper, Averting Malpractice By Information: Informed Consent in the Pediatric Treatment Environment, 47 DEPAUL L. REV. 819, 821-22 (1998) (suggesting initiation of a broad survey to learn what occurs when children are informed about treatment decisions); see also Julie A. Koehne, Witnesses on Trial: Judicial Intrusion Upon the Practices of Jehovah's Witness Parents, 21 FLA. ST. U. L. REV. 205, 207 (1993) (arguing that Jehovah's Witnesses should be able "to adhere to the principles of their chosen faith and raise their children accordingly without interference from courts").

162141 U.S. 250 (1891). 
own person, free from all restraint or interference of others." 163 The Botsford court specifically held that an individual could not be forced to submit to unwanted medical treatment. ${ }^{164}$ The Court has affirmed this right in more recent cases, including the so-called "right to die case": Cruzan v. Director, Mo. Dep't of Health. ${ }^{165}$ Although some have declared that Cruzan finally established a constitutional right to $\mathrm{die}^{166}$ the Court only stated that "a competent person has a constitutionally protected liberty interest in refusing unwanted medical treatment." ${ }^{, 167}$ Thus, a patient who may give consent to a treatment plan may also withhold consent and either forego all treatment or seek alternative methods. ${ }^{168}$

On the contrary, when it comes to treatment decisions for minors, the right of informed consent does not rest with the adolescent patient, it rests with his or her parents or legal guardians. ${ }^{169}$ If a parent refuses "necessary" treatment, the state can challenge that decision, claiming neglect, and can obtain both temporary legal custody and the authorization to make treatment decisions for the minor child. ${ }^{170}$ The minor's wishes and desires are virtually ignored. ${ }^{171}$ Occasionally, the parents will agree with the physicians on the preferred course of treatment, but the minor will disagree. ${ }^{172}$ When the minor's choice is different than that of his or her parents and physician, litigation is unlikely because there is not a legal

163 Id. at 251.
164 Id. at 257.

165

497 U.S. 261, 269 (1990) (stating that value of bodily integrity is embodied in the doctrine of informed consent). See also Rochin v. California, 342 U.S. 165,175 (1952) (holding that forced stomach pumping is "offensive to human dignity."); Schmerber v. California, 384 U.S. 757, 772 (1966) (stating that the "integrity of an individual's person is a cherished value in our society.").

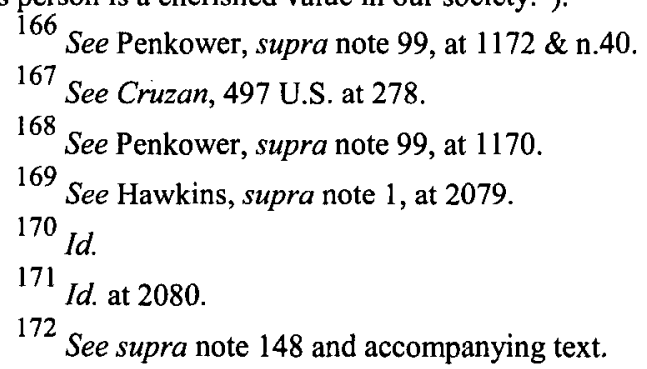


process that allows a minor to challenge the parent's consent. ${ }^{173}$ Thus, when an unemancipated minor needs medical treatment, with the exception of an abortion or treatment for a sexually transmitted disease, the premise that minors are incapable of making informed decisions and that adults know best prevails. ${ }^{174}$

\section{B. Adolescents Are Capable of Making Informed Decisions}

Crucial to successful medical treatment is the consent, cooperation, and participation of the patient. ${ }^{175}$ The medical community, as well as some legal scholars, have realized that minors should be allowed to participate in determining what course their medical treatment should take and that minors are in fact capable of doing so. ${ }^{176}$ In fact, researchers have found "that children often are capable of making important life decisions in a rational matter, including decisions about medical and psychological treatment."177 Further, if a minor is included in the decision-making process and provides informed consent for his or her treatment the effectiveness of the treatment will improve. ${ }^{178}$

173 See Hawkins, supra note 1, at 2080 (hypothesizing that even if a mechanism existed courts would probably not consider the case on the basis that minors lack legal standing and parents have ultimate authority over their children).

174 See, e.g., Parham v. J.R., 442 U.S. 584, 603 (1979) (stating "most children, even in adolescence, simply are not able to make sound judgments ... including their need for medical care or treatment. Parents can and must make those judgments."); see also Popper, supra note 161, at 833 (discussing results of a survey of pediatricians in which more than half agreed that "parental anxiety or other factors . . . cause many parents to consent ... without fully exploring the alternatives and risks of treatment").

${ }^{175}$ See Michael A. Grodin \& Joel J. Alpert, Informed Consent and Pediatric Care, in ChILDREN's COMPETENCE to CONSENT, 93 at 94 (Gary B: Melton et. al. eds., 1983); see also Redding, supra note 34, at 709 (stating that "[c]linicians agree treatment outcomes are poor when children are forced to receive treatment").

176

See Redding, supra note 34 , at 708; see also Hawkins, supra note 1, at 2118-19; Weir, supra note 59, at 31.

${ }^{177}$ See Redding, supra note 34, at 707.

178

See Redding, supra note 34, at 709 (discussing the impact of recent research on the traditional views of children's competence); see also Popper, supra note 161 , at 826 (stating that "the rate and quality of healing and recovery is higher with 
Recognizing the discrepancies in statutory and case law, the American Academy of Pediatrics Task Force ("the Task Force") issued guidelines for physicians who treat minors. ${ }^{179}$ The Task Force declared that if the procedure is either elective surgery or treatment and the minor is thirteen years of age or older, the minor's written consent should be obtained. ${ }^{180}$ In addition, the Task Force suggested that children older than seven years of age should be provided an opportunity to also consent or assent to treatment. ${ }^{181}$ In determining whether a child between seven and thirteen years old is able to comprehend the implications of undergoing or foregoing a medical procedure, the Task Force instructs pediatricians to consider the child's "age, disease, severity, prognosis, risks, and proposed benefits of therapy," as well as expert opinions concerning the adolescent "patient's level of intelligence, reasoning ability, and emotional state." 182

Adolescents as young as twelve years of age are capable of understanding the nature of their medical problems. ${ }^{183}$ Some

informed patients than with those who do not understand the nature of their treatments"). 179

See American Academy of Pediatrics, Task Force on Pediatric Research, Informed Consent, and Medical Ethics, Consent, 57 PEDIATRICs 414, 415 (1976); see also Weir, supra note 59, at 32 (discussing the Pediatric Bill of Rights, adopted by the National Association of Children's Hospitals in 1974, which states any minor "who is of sufficient intelligence to appreciate the nature and consequences of the proposed medical care and if such medical care is for his own benefit, may effectively consent to such medical care in doctor-patient confidentiality"); The United Nations Convention on the Rights of the Child, G.A. Res. 44/25, U.S. GAOR, 44th Sess., Supp. No. 49 at 166, U.N. Doc. A/44/736 (1989), revised by U.N. doc. A/RES/44/25/Corr.1 (1990), reprinted in 28 I.L.M. 1456 (1989). "States Parties shall assure to the child who is capable of forming his or her own views the right to express those views freely in all matters affecting the child, the views of the child being given due weight in accordance with the age and maturity of the child." Id. President Clinton signed the Convention in 1995, however, the United States Congress has not ratified the Convention.

${ }^{180}$ See Grodin \& Alpert, supra note 175, at 95 (detailing the proclamations of the American Academy of Pediatrics).

$$
\begin{aligned}
& 181 \\
& { }_{182} \\
& \text { Id } \text { Id. }
\end{aligned}
$$

${ }^{183}$ See generally Redding, supra note 34 , at 708 ; Grodin, supra note 175 , at 96-97; Weir, supra note 59, at 31; Traugott \& Alpers, supra note 38, at 924 . The variation in an agreed upon age of competency lends further support for the need to evaluate a minor's competence on an individual basis. See Rosato, supra note 41, at 51. 
professionals are concerned that adolescent patients, who by nature are seeking to establish their independence and individualism, may choose a course of treatment that is not within their best interests in an effort to gain the acceptance of their peers or defy their parents. ${ }^{184}$ However, this is not true of all adolescents. ${ }^{185}$ Thus, it is imperative for physicians to put aside preconceived notions of adolescent nature and focus on the individual adolescent patient's maturity and capacity. ${ }^{186}$

The problem however, is that the courts continue to rely on "traditional assumptions about children's abilities, and idealistic views about the role of parents in making decisions for their children." 187 Thus, if the physician follows the Task Force guidelines ${ }^{188}$ and respects the adolescent patient's choice to refuse treatment the state may still intervene and consent to the procedure against the wishes of the patient and parents. ${ }^{189}$

\section{When The Adolescent SHOuld DeCide}

Since adolescents are capable of making competent decisions, the question becomes whether it is appropriate for them to do so and what limitations, if any, should be placed on their decision-making

${ }^{184}$ See Grodin \& Alpert, supra note 175, at 96; see also Traugott \& Alpers, supra note 38 , at 924 .

${ }^{185}$ See Grodin \& Alpert, supra note 175 , at 96-97.

${ }^{186}$ Id. at $96-97$. Grodin and Alpert also point out that the type of illness is a critical factor in determining the significance to be placed on a minor's articulated desire. $I d$. at 97 . Thus, the more chronic disease the more likely that the minor is capable of making an informed, competent decision, based on a significant history of dealing with the illness. Id.

${ }^{187}$ Redding, supra note 34, at 705 and discussion of United States Supreme Court cases at 705-06.

188 But see Popper, supra note 161, at 822. "In practice, however, 'few children are asked if they agree ... to having a blood test, or to being given a drug, or to having an operation."' Id. (quoting George Rylance, Making Decisions with Children: A Child's Rights to Share in Health Decisions Can No Longer Be Ignored, 312 BRIT. MED. J. 794, 794 (1996)).

${ }^{189}$ See supra notes $148-152$ and accompanying text. 
process. Many children's rights advocates believe that a presumption of competence should be extended to adolescents, allowing them to make medical treatment decisions unless proven incompetent. ${ }^{190}$ Changing this exception and extending the fundamental right of informed consent and bodily integrity to adolescents will grant greater autonomy and freedom to the minor and will place the burden on those who wish to abridge these rights. ${ }^{191}$

Medical decisions are premised on the belief that the treatment chosen will promote the best interests of the patient. Supposedly, this will mean that the expected benefits of treatment will outweigh the possible harms. ${ }^{192}$. Thus, in making the decision several factors, such as the quality and duration of life, the adverse effects and duration of therapy, and the likelihood of success, will be important variables in deciding what form of treatment is best for the individual adolescent. ${ }^{193}$ Values and cultural perspectives will also play a very important role in determining the appropriate course of treatment. ${ }^{194}$ For some adolescent patients, quality of life, during what is inevitably the end-stages of a terminal illness may be more important than extended treatment with limited benefits. ${ }^{195}$ Other adolescent patients may place a higher value on the ability to play and interact with peers instead of being hospitalized. ${ }^{196}$

The ability to cure a minor's illness is also an important factor in considering whether to order treatment regardless of objections by the parents or the minor. ${ }^{197}$ There is currently an indication that the

${ }^{190}$ See Hawkins, supra note 1, at 2129 (putting forth the ideas of children's rights advocates Hillary Rodham Clinton and Henry Foster's position "that the presumption that children are incompetent should be set aside"). See also Weir, supra note 59, at 36 (advocating for a rebuttable presumption of competence in adolescents between fourteen and seventeen).

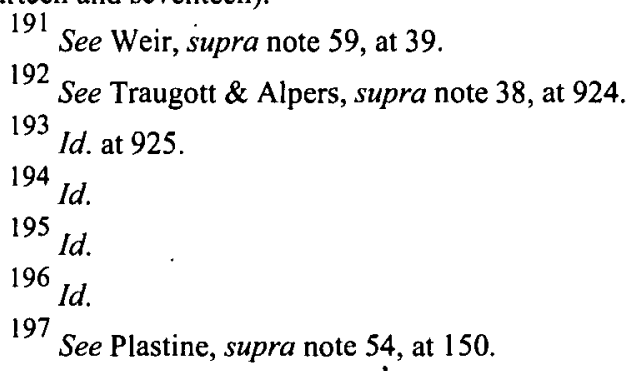


courts will be more willing to respect the adolescent patient's or the parents' choice if the child is suffering from an incurable affliction. ${ }^{198}$ For instance, in Newmark v. Williams, ${ }^{199}$ the Supreme Court of Delaware held that Colin Newmark was not a neglected child under Delaware law, and the State could not intervene and compel treatment because the egregious facts of Colin's case outweighed the State's authority to intervene in the parent-child relationship. ${ }^{200}$ Colin suffered from a deadly form of pediatric cancer and the proposed course of treatment offered less than a $40 \%$ chance of "success."201 Although Colin was too young to be involved in deciding what treatment would be utilized, ${ }^{202}$ his parents, practicing Christian Scientists, ${ }^{203}$ desired to treat their son spiritually through prayer

198

See, e.g., Newmark v. Williams, 588 A.2d 1108 (Del. 1991); See In re

Philip B., 156 Cal. Rptr. 48 (Cal. Ct. App. 1979), cert. denied, 445 U.S. 949 (1980) (upholding parents' constitutional right of parental autonomy by respecting their decision to withhold cardiac surgery for their twelve year old child who was suffering from a congenital heart deformity and Down's syndrome); In re Green, 292 A.2d 387 (Pa. 1972) (upholding wishes of parents who refused blood transfusions for child with paralytic scoliosis); In re D.P., No. 91950 (Santa Clara County Juv. Ct. July 3, 1986) (holding that fourteen year old cancer patient who refused blood transfusions could not be kept in the hospital against her will). But see In re Sieferth, 127 N.E.2d 820 (N.Y. 1955) (declining to order surgery to correct child's cleft palate and harelip when there was no serious threat to child's life or health).

199588 A.2d 1108 .

200 Id. at 1118 . The Court focused on the nature of the proposed treatment, stating that it was "highly invasive, painful, involved terrible temporary and potentially permanent side effects, posed an unacceptably low chance of success, and a high risk that the treatment itself would cause death." Id.

201 See id. at 1109-10. Colin was only three years old when diagnosed with Burkitt's Lymphoma. Id.

202 Although Colin was unable to make his own treatment decisions, this case illustrates that the courts are not going to order treatment over objections of those legally authorized to give consent if the illness is incurable. Should the laws be expanded to grant adolescents the right to give or with hold consent this premise would likely apply. Id. at 1118 .

203 The First Church of Christ, Scientist, was founded in 1879 by Mary Baker Eddy and teaches its members that diseases and sickness are manifestations of the mind that can be overcome by praying and drawing closer to God. See Janna C. Merrick, Christian Science Healing of Minor Children: Spiritual Exemption Statutes, First Amendment Rights, and Fair Notice, 10 IssuES L. \& MED. 321, 325 (1994); see also 
instead of with chemotherapy. ${ }^{204}$ In contrast, when a minor's condition is life threatening, but curable, courts have declared minors neglected when parents withhold consent for treatment. ${ }^{205}$ Further, the courts will intervene even in situations where the minor's affliction is not life threatening. ${ }^{206}$ Thus, the courts will be less likely to intervene and order medical treatment as "the level of bodily invasion rises and the prognosis dims.",207

\section{A. The Physician's Role}

The physician has a key role in the decision-making process, and that role should begin long before choosing or implementing the course of treatment. ${ }^{208}$ The physician must educate both the adolescent and his or her family about treatment options and expected outcomes and negotiate a treatment plan that is acceptable to everyone

Elizabeth A. Lingle, Treating Children by Faith Colliding Constitutional Issues, $17 \mathrm{~J}$. LEGAL MED. 301, 306 (1996).

${ }_{204}^{204}$ See Newmark, 588 A.2d at 1109.

205 See, e.g., People ex rel. D.L.E., 645 P.2d 271 (Colo. 1982) (holding that when parents refuse medical treatment for their child on religious grounds, the state can meet its burden by demonstrating that the child suffers from a life-threatening, but curable condition); In re Ivey, 319 So. $2 \mathrm{~d} 53$ (Fla. Dist. Ct. App. 1975) (ordering bloodtransfusions for a child whose life was endangered by the parents refusal to consent to the procedure); In re McCauley, 565 N.E.2d 411 (Mass. 1991) (holding that life-saving blood transfusions were in the best interest of the child and outweighed the parents' constitutional objections).

206 See, e.g., In re Eric B., 235 Cal. Rptr. 22 (Cal. Ct. App. 1987) (ordering periodic monitoring of child to detect possible reoccurrence of cancer over parents' religious objections); In re Karwath, 199 N.W.2d 147 (Iowa 1972) (ordering surgical removal of child's tonsils and adenoids over father's religious objections); In re Sampson, 317 N.Y.S.2d 641 (N.Y. Fam. Ct. 1970), aff'd, 323 N.Y.S.2d 253 (N.Y. App. Div. 1971), aff'd, 278 N.E.2d 918 (N.Y. 1972) (ordering child to undergo a risky surgical procedure that would partially correct, but not cure, child's non-life-threatening facial deformity, over his mother's religious objections); In re Gregory S., 380 N.Y.S.2d 620 (N.Y. Fam. Ct. 1976) (upholding state intervention where mother refused medical and dental care for child suffering from cavities, fractured teeth, and an umbilical hernia); Mitchell v. Davis, 205 S.W.2d 812 (Tex. Civ. App. 1947) (holding that mother's faith in spiritual healing was not a defense to a prosecution for child neglect where mother refused to provide medical treatment for son's arthritic knee).

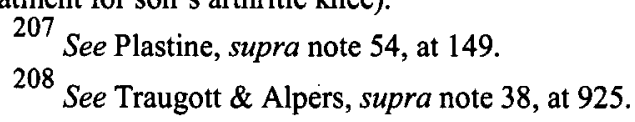


involved. $^{209}$ Thus, the physician's first task is to provide the adolescent patient, as he or she would any patient, with information about his or her diagnosis, the nature of the recommended procedure including the risks, and the prognosis if the procedure is performed as well as other alternative medical treatments. ${ }^{210}$ However, the physician must simultaneously determine the "adolescent's decisionmaking capacity by determining whether he or she understands the recommended therapy, the alternatives, the risks and the benefits, and the likely consequences of refusal."211 Based on the close relationship with the adolescent patient and daily experience with adolescents with same or similar conditions, the physician is the most qualified to determine whether the minor is capable of making an informed and competent decision. ${ }^{212}$ Should a dispute arise between the parents' and the adolescent's choice of treatment, the physician should act as a negotiator to facilitate a compromise. ${ }^{213}$ In doing so, the physician should use the same criteria to evaluate the parents' decision, and assess the overall relationship between the adolescent and his or her parents. $^{214}$ As a negotiator, the physician must listen to and acknowledge the adolescent patient's concerns. ${ }^{215}$ By carefully listening to the adolescent patient's reasons for refusal or for choosing one therapy over another, the physician will be better able to address and alleviate the concerns, which may actually lead to the adolescent accepting a beneficial treatment that he or she was originally

${ }^{209}$ Id.

${ }^{210}$ See Penkower, supra note 99, at 1170. See also supra notes $157-160$ with accompanying text.

211 See Traugott \& Alpers, supra note 38, at 925.

212 See Waters, supra note 78, at 113-14 (suggesting that "trained and qualified medical professionals can best determine an individual minor's maturity and best interests"). The United States Supreme Court has upheld medical-review procedures in other areas. See, e.g., Parham v. J.R., 442 U.S. 584, 607 (1979) (conditioning parental decision to commit a child to a state's mental hospital on an independent review by the state's hospital authorities).

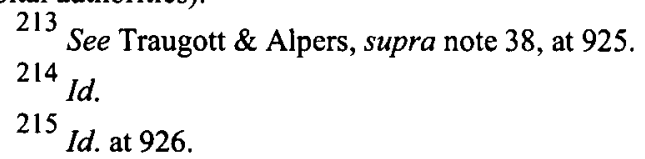


unwilling to undergo. ${ }^{216}$

When the conflict is severe, hospital ethics committees can assist in this process. ${ }^{217}$ All hospitals are required by the Joint Commission on Accreditation of Healthcare Organizations to implement process for resolving patient care disputes. ${ }^{218}$ It is suggested that such committees include an expert in adolescent medicine, such as an adolescent psychiatrist or psychologist, and if a non-Western culture is involved, a representative of that community. ${ }^{219}$ If the dispute can be resolved at this level, child welfare officials or courts will not need to become involved. ${ }^{220}$

As discussed above, the best interests of the adolescent patient will control, however, non-medical factors may be as important as medical factors in determining what is the best interest of the adolescent patient, especially if the adolescent places great weight on them. ${ }^{221}$ Thus, the physician should consider the quality of life as well as the duration of life when determining what is in the adolescent patient's best interest. ${ }^{222}$

The cultural perspective of the patient and his or her family is also a crucial factor that must be considered. ${ }^{223}$ The Lor case ${ }^{224}$

${ }^{216}$ Id. Adolescents tend to be particularly concerned with peer acceptance. Id. For instance, a refusal to undergo chemotherapy treatment, may be, in part, out of concern for physical appearance at an important upcoming social occasion. Id.

217 See Traugott \& Alpers, supra note 38, at 926.

218 Id.

219 Id.; see also Rosato, supra note 41, at 13-14 (discussing how treatment decisions "shape the definition of one's entire life"). 220

Id.; see also Redding, supra note 34 , at 739 . With respect to mental health treatment Redding suggests that a clinician and attorney work as a team to determine whether a minor is capable of giving consent; the attorney guarding the legal rights of the child and the clinician assessing the child's ability to consent. Id. This system may also work in other medical situations, although it may be more cumbersome than necessary. Id. at $739-40$

${ }^{221}$ See Traugott \& Alpers, supra note 38 , at 926.

222 Id. See also supra note 208 and accompanying text.

223 See Traugott \& Alpers, supra note 38, at 925.

${ }^{224}$ See sources cited supra note 149 and accompanying text for a discussion of the Lor case. 
illustrates how non-Western cultures may have different views about the adolescent's best interest. ${ }^{225}$ In cases such as this one, the physician should consider whether the adolescent embraces the values of his or her culture and whether non-Western treatment may be a viable alternative. ${ }^{226}$ Above all, the physician should maintain a sense of neutrality; by not imposing his or her beliefs and value system on the adolescent and, instead, should respect the views of the informed adolescent. $^{227}$

\section{B. The Court's Role}

Involvement of the court in the treatment decision may only further exacerbate the situation between the adolescent, family, and physicians. However, until adolescents in all jurisdictions are afforded the constitutional right to give informed consent, and even once this right is granted, it may, at times be necessary to resort to litigation and involve judges in the decision-making process. ${ }^{228}$ When agreement cannot be reached regarding an adolescent's medical treatment, either the physician, hospital, or state may request the court to authorize treatment, or empower a third party with the right to consent on behalf of the patient. ${ }^{29}$

When deciding who gets to choose the course of medical treatment, the judge "should not assume that a broad parental autonomy right dictates the outcome." 230 Instead, the judge should focus on the best interests of the adolescent patient, granting more weight to the adolescent's wishes, while not ignoring the positions of the physicians, the state, and the parents. ${ }^{231}$ In fact, many, if not all,

${ }^{225}$ See Traugott \& Alpers, supra note 38, at 925.

226. Id.

227 Id.

228

229 Id.

230

See Sher, supra note 35, at 184

231 See Traugott \& Alpers, supra note 38, at 926; see also Rosato, supra note 41 , at 50 (arguing the "judge's initial and most important determination will be whether the minor demonstrated his maturity by clear and convincing evidence"). 
of the factors the physician needs to assess in determining the adolescent patient's ability to consent should also be considered and weighed by the judge. ${ }^{232}$

In evaluating a case, the courts should utilize experts in adolescent medicine in order to obtain a reliable understanding of the particularities of the adolescent's case. ${ }^{233}$ These experts should interview the patient and offer testimony both about the decisionmaking capabilities of the typical adolescent and this particular individual. ${ }^{234}$ If based on all of the testimony, the court concludes that the adolescent is capable of making an informed decision, the adolescent's choice should be respected. ${ }^{235}$ If the adolescent is not capable of making such a decision, the alternative would be to determine which treatment option would be in the adolescent patient's best interest. $^{236}$

The judicial bypass procedure authorized in Bellotti ${ }^{237}$ is an alternative method which allow adolescents to seek the medical treatment they desire. ${ }^{238}$ In a judicial bypass hearing the judge would determine if the minor has the maturity and capability to consent to treatment. ${ }^{239}$ This type of legal proceeding most likely would occur if the parents and adolescent were in conflict as to the preferred course

232 See supra Part V.A. Professor Rosato also argues that a state's interest should only prevail if "treatment is nonexperimental and when a significant probability exists that the condition or disease will be cured or that the major symptoms of the condition will be alleviated in the foreseeable future." See Rosato, supra note 41, at 50, 68-69, \& 83-87. This argument would result, for example, in court ordered blood transfusion of a Jehovah's Witness if such treatment would save his or her life. Similarly, the court would have been forced to reach a different conclusion in the Swan case. See discussion supra notes 131-137 and accompanying text. See also Rosato, supra note 41, at $87-94$.

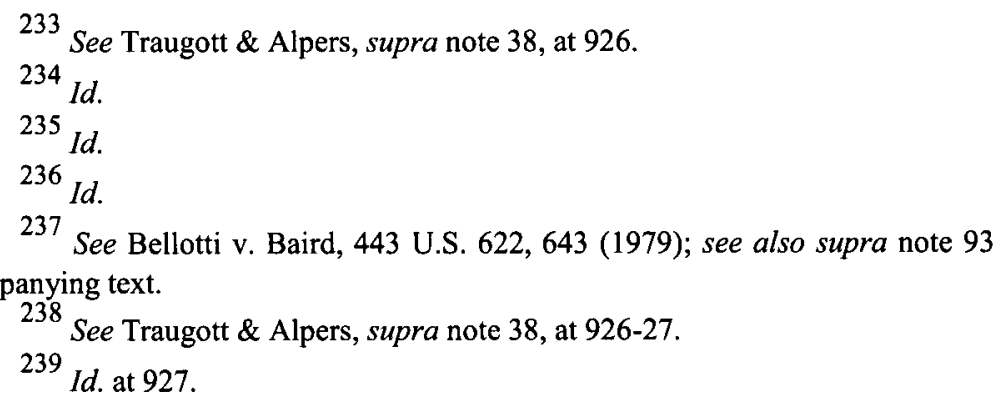


of treatment and neither the hospital nor state intervened first. ${ }^{240}$ Such a mechanism would place the burden on the adolescent patient to take legal action in order to have his or her choice considered. ${ }^{241}$ In cases where the adolescent is seriously ill this may be a very difficult, if not impractical, option. ${ }^{242}$ Thus, a more practical approach would be to allow the physician to assess the adolescent's decision-making capacity, as discussed above, and only resort to a court procedure in the most extreme cases. ${ }^{243}$

\section{CONCLUSION}

The exceptions that the Supreme Court and legislatures have made with regard to an adolescent's ability to consent to medical treatment are inconsistent with the traditional legal doctrine that a minor is incapable of giving consent. However, research has shown that adolescents are in fact as capable of making complex decisions as adults. $^{244}$ In light of this fact, the law should give way to the trend established in the areas of emancipation and abortion and embrace the mature minor doctrine.

Under the current scheme, a presumably immature minor may still obtain an abortion. Furthermore, if the minor opts to have the child, she has legal authority to make medical decisions for the child, regardless of the fact that she is prohibited from making any medical treatment choices for herself. In contrast, a mature adolescent, who has dealt with the complexities of an incurable illness, does not have a legal voice in deciding treatment. In addition, the inconsistencies that exist make it extremely difficult to know whether a court will intervene and to what extent. ${ }^{245}$ What has happened is the legislature

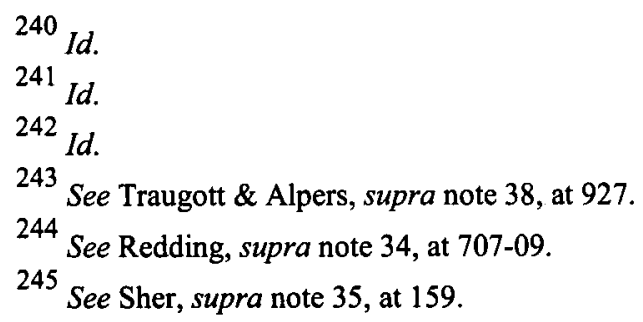


and courts have reacted to specific teen "crises," such as pregnancy and sexually transmitted disease, and have not actually carved out these consent exceptions because they believe minor's have a right to privacy or self-determination. ${ }^{246}$

These inconsistencies make it clear that there is a need to reevaluate whether adolescents should be allowed to consent to medical care. Based on the Supreme Court's declaration that minors have constitutional rights, including the right to privacy, ${ }^{247}$ and minors ability to make complex decisions a rebuttable presumption of competency should be granted to adolescents. This presumption of capacity should only be challenged if there is strong evidence that the adolescent is actually incompetent to make such important decisions. The adolescent's physician should play the paramount role in assessing the adolescent's decision-making ability. Where conflict arises that the physician is incapable of resolving through negotiation with the adolescent and the adolescent's parents, a hospital ethics committee would be the next appropriate dispute resolution method. The courts should only be used as a last resort in resolving conflict. The few states that have recognized the mature minor doctrine have realized that age is an arbitrary method of determining capacity. It is time that the rest of the legal community also acknowledge this obvious principle. By creating this rebuttable presumption adolescents will finally enjoy their rights of informed consent, bodily integrity, self-determination, and privacy to the fullest extent.

Christine M. Hanisco

246 See Walter J. Wadlington, Consent to Medical Care for Minors, in CHILDREN's COMPETENCE To CONSENT 57, 73 (Gary B. Melton et. al. eds., 1983); see also Rosato, supra note 41, at 29.

247 See discussion supra notes 73-99 and accompanying text. 